THE ARTS

CHILD POLICY

CIVIL JUSTICE

EDUCATION

ENERGY AND ENVIRONMENT

HEALTH AND HEALTH CARE

INTERNATIONAL AFFAIRS

NATIONAL SECURITY

POPULATION AND AGING

PUBLIC SAFETY

SCIENCE AND TECHNOLOGY

SUBSTANCE ABUSE

TERRORISM AND HOMELAND SECURITY

TRANSPORTATION AND INFRASTRUCTURE

WORKFORCE AND WORKPLACE
This PDF document was made available from www.rand.org as a public service of the RAND Corporation.

Jump down to document $\nabla$

The RAND Corporation is a nonprofit research organization providing objective analysis and effective solutions that address the challenges facing the public and private sectors around the world.

\section{Support RAND}

$\underline{\text { Browse Books \& Publications }}$

Make a charitable contribution

\section{For More Information}

Visit RAND at www.rand.org

Explore RAND Testimony

View document details
Limited Electronic Distribution Rights

This document and trademark(s) contained herein are protected by law as indicated in a notice appearing later in this work. This electronic representation of RAND intellectual property is provided for non-commercial use only. Unauthorized posting of RAND PDFs to a non-RAND Web site is prohibited. RAND PDFs are protected under copyright law. Permission is required from RAND to reproduce, or reuse in another form, any of our research documents for commercial use. For information on reprint and linking permissions, please see RAND Permissions. 


\title{
Health Insurance Market Rating Practices
}

\author{
JOHN BERTKO
}

CT-315

September 2008

Testimony presented before the Senate Finance Committee on September 23, 2008

This product is part of the RAND Corporation testimony series. RAND testimonies record testimony presented by RAND associates to federal, state, or local legislative committees; government-appointed commissions and panels; and private review and oversight bodies. The RAND Corporation is a nonprofit research organization providing objective analysis and effective solutions that address the challenges facing the public and private sectors around the world. RAND's publications do not necessarily reflect the opinions of its research clients and sponsors. RAND ${ }^{\circledR}$ is a registered trademark. 
Published 2008 by the RAND Corporation 1776 Main Street, P.O. Box 2138, Santa Monica, CA 90407-2138

1200 South Hayes Street, Arlington, VA 22202-5050 4570 Fifth Avenue, Suite 600, Pittsburgh, PA 15213-2665

RAND URL: http:/ / www.rand.org

To order RAND documents or to obtain additional information, contact

Distribution Services: Telephone: (310) 451-7002;

Fax: (310) 451-6915; Email: order@rand.org 


\section{John Bertko, FSA, MAAA ${ }^{1}$ \\ Adjunct Staff, The RAND Corporation \\ Former Chief Actuary, Humana Inc. \\ Health Insurance Market Rating Practices ${ }^{2}$ \\ Before the Committee on Finance \\ United States Senate}

\section{September 23, 2008}

Chairman Baucus, Ranking Member Grassley, and members of the Committee on Finance, my name is John Bertko, and I am honored to have the opportunity to testify before you today about the rating practices of the private health insurance market.

The private health insurance market in the U.S. is frequently described as three separate segments: the Individual insurance market, the small group segment for employers with 2 to 50 employees, and the large group segment for employers with more than 50 employees. Each segment has different rating practices and regulation. To give an idea of the size of these segments, there are:

- About 17 million covered individuals in the Individual Insurance market

- About 30 million in the Small Group market

- More than 120 million in the Large Group market.

Rating practices, or setting premium rates, differ for each of the segments and also differ by state. Premium rating is mostly regulated by state insurance law but also follows the requirements of several federal laws, including ERISA (for large employers mainly), COBRA (for extension of benefits coverage) and HIPAA (for certain provisions related to group insurance waiting periods and insurance continuation plans). I will provide a very brief summary of the rating methods used by private health insurers.

\footnotetext{
${ }^{1}$ The opinions and conclusions expressed in this testimony are the author's alone and should not be interpreted as representing those of RAND or any of the sponsors of its research. This product is part of the RAND Corporation testimony series. RAND testimonies record testimony presented by RAND associates to federal, state, or local legislative committees; government-appointed commissions and panels; and private review and oversight bodies. The RAND Corporation is a nonprofit research organization providing objective analysis and effective solutions that address the challenges facing the public and private sectors around the world. RAND's publications do not necessarily reflect the opinions of its research clients and sponsors.

2 This testimony is available for free download at http://www.rand.org/pubs/testimonies/CT315/.
} 


\section{Individual Health Insurance Segment}

For the Individual health insurance market, there are two distinct approaches to rating methods allowed by states. For five states, insurers in those states must offer policies to all applicants (guaranteed issue) and are limited to rates that are similar regardless of health status, called adjusted community rating. For these states, rates will generally vary by age and gender but not with health conditions.

In the other states, individual health insurance policies are underwritten, meaning that past health conditions of individuals are examined and rates are set according to the health risk of the applicant. Generally, there are three possible outcomes:

- An applicant answers a variety of health status questions and is underwritten as a "standard risk" and receives an offer of insurance at standard rates that are generally lower than those for an employee or dependent in the employer market. This occurs since the person is found to be healthy at time of policy issue, rather than being of "average health" typical of an employee or dependent of an employee.

- An applicant with some past or current health conditions might be offered a policy at higher rates than average (called a "rate up" offer) or with coverage of certain specified conditions excluded for a period of time (called a "pre-ex" offer).

- Some applicants with more serious health conditions will be denied coverage since the insurer would not be able to charge a sufficient premium in an underwritten market to pay for the average claims for these individuals.

In underwritten markets, about $70 \%$ of applicants will qualify for standard policies, about $15-20 \%$ will be offered policies at higher rates or with pre-existing conditions not covered and about 10$15 \%$ of applicants will not be offered any coverage. Additionally, agents or brokers may inform some individuals interested in obtaining coverage that they are likely to be denied coverage, so there is another group of people who do not apply for individual insurance coverage at all.

Individual health insurance rates in states allowing underwriting can vary with age and gender and with health status. On average, rates for the under-65 population may vary by an actuarial factor of 6:1 (or so) without regard to health status, meaning that rates for the oldest group (say, in the 60-64 year old bracket) will be six times the rate for the youngest adults (18-24 year old bracket). Some states place restrictions on the total variance of premium rates, including health status, but generally rates offered to those with health conditions will not exceed twice standard rates offered to the healthy individuals of the same age. 
In 32 states, individuals who are denied coverage might be able to obtain coverage from High Risk Pools (HRPs), if they can afford the HRP premium and there is capacity in the HRP. About 200,000 Americans are covered by HRPs, with an average of about 6000 individuals in each state HRP. Premiums in the HRP are usually $200 \%$ to $250 \%$ of standard premiums paid by individual applicants and are heavily subsidized by insurance assessments or other funding sources in addition to the premiums charged. Access to a HRP is generally limited by the amount of subsidy available in a state and by the ability of a HRP applicant to afford the higher HRP premium.

\section{Small Employer Segment}

In the Small Group (SG) market, all states have followed HIPAA provisions and require Guaranteed Issue. This means that any small employer will be made an offer of insurance as long as certain requirements are met: typically, these include some minimum employer contribution requirement and participation or alternative coverage for all or nearly all employees.

Premium rates in the SG market are generally subject to rating band limitations, determined first based on "case characteristics," consisting of age and gender of employees, location, number of employees and type of insurance product, which determine the "manual" or average rate for a premium. Then, in most states a factor for health status or industry is applied to calculate premium rates within certain rate bands. Model legislation from the National Association of Insurance Commissioners (NAIC) specifies that rates may deviate from the manual rate by no more than + or $-35 \%$. However, there are variations in many states and the most common rate band is $+/-25 \%$. A few states also specify Adjusted Community Rating in which no variation by health status or other factors is allowed.

\section{Large Employer Segment}

For large employers with more than 50 employees, premium rates are determined either from an individual firm's claims experience or from a blended average of manual rates and claims experience. Firms with 500 or more employees are almost always experience-rated, meaning that their past year of claims experience is projected with health insurance trend to determine future premium rates. In addition, many of these firms are self-funded, meaning that the insurance risk for future claims is borne entirely by the employer, perhaps using re-insurance as protection against the possibility of catastrophic claims. For both these larger firms and for the smaller firms 
choosing to purchase insurance, there are generally no restrictions on premium rates that are charged.

Regulation of the large employer market is split between limited state regulation and ERISA.

Some states regulate all health insurance rates to assure that they are necessary and adequate, but without formal limits on rates that can be charged. Larger self-insured employers generally use the ERISA exemption from state regulation to allow them to offer the same benefits for multistate locations.

\section{Key Issues}

There are at least two major issues in private health insurance market today: affordability and access. As you may know, the average health insurance premium this year is around $\$ 13,000$ for a family covering two adults and children. Even with an average employer subsidy of $75 \%$, this amounts to an employee payroll deduction for health insurance of over $\$ 3000$ per year for the average employee. Out of pocket cost sharing generally amounts to about $20 \%$ of covered services in addition to payroll deductions for premiums.

Access to employer-provided insurance is generally on a guaranteed issue basis, except for waiting periods limited to no more than 12 months for employees who do not have a history of prior coverage. In the individual market, some individuals with health conditions may be denied coverage if they have serious conditions. For other individuals with less serious conditions, they may have coverage of these conditions excluded for a period of time or be required to pay more than for standard policies.

Thank you for the opportunity to provide this brief summary of rating and underwriting practices in the private health insurance market. I would be glad to answer questions about my testimony. 